\title{
Operational river ice and water temperature forecasting on the Hungarian Danube reach
}

\author{
Zoltán Árpád Liptay ${ }^{1}$, a, Balázs Gauzer ${ }^{1}$ \\ ${ }^{1}$ General Directorate of Water Management, Hungarian Hydrological Forecasting Service, Budapest, 1012, Márvány u. 1/d., Hungary
}

\begin{abstract}
The operation river ice and water temperature forecasting system of the Hungarian Hydrological Forecasting Service is based on a dual approach. The estimation of the energy balance of the Danube River is carried out as a physical approach that incorporates all available hydro-meteorological data and on the other hand a conceptual method is taken into consideration based on the relationship of air and stream temperatures. Both of the methods are results of continuous research and are fine-tuned for state-of-the-art performance on the Hungarian Danube reach. Superior calibration and validation results $\left(0.27-0.68^{\circ} \mathrm{C}\right.$ on a 10 -day lead time for validation) were achieved compared to other published cases of recent years dealing with similar or larger rivers.
\end{abstract}

\section{Introduction}

The increasing intensity of the hydrological cycle caused numerous flood events during the past years, but the circumstances necessary for river ice occurrence were observed only a few times, and the two phenomena rarely occur together. Such a rare event was the ice occurrence on the Danube River in 2017, and the quickly following icy flood on the Tisza river. These events highlighted that rivers can still present unexpected challenges in river ice management. A comprehensive report on these events were published by the International Commission for the Protection of the Danube River (Mladenović et al. 2018). These events are hazards with both economical and human impact thus their safe management is priority but a complex engineering task. The forecast and preparation for these events are among the main tasks of protection.

The importance of river ice prediction on the Danube river is a well-known fact for more than a century in order to fully exploit the autumn navigation season, which is still one of the key reasons for river ice prediction because floating ice sheets often of $60 \mathrm{~cm}$ thickness and 5 metres of diameter (Keve 2012) can cause severe damage to ships and ferries, not just risking cargo but crew and passengers. Industrial utilization such as hydroelectric power generation or cooling-water of fossil and nuclear power plants is another key reason for river ice and water temperature prediction due to environmental regulations of cooling-water outlets. Moreover river related recreation and entertainment services can also rely on water temperature forecasts. River ice prediction is heavily dependent on water temperature forecast, thus sufficient efficiency is only obtainable through a reliable water temperature model.

Regarding to the classification of Benyahya et al. (2007) most of the water temperature models are either deterministic (D) or statistic (S). Deterministic models are mathematical representations of the physical processes, generally based on the energy balance approach, while statistical models are classified into either parametric (S/P) (regression and stochastic models) or non-parametric (S/NP) models (machine learning, artificial neural networks).

Calibration and validation results of five statisticallyand seven deterministically-based former studies are presented in Table 1. While the RMSEs ranged between $0.5^{\circ} \mathrm{C}$ and $1{ }^{\circ} \mathrm{C}$ for rivers of $\mathrm{Q}_{\text {mean }}<500 \mathrm{~m} 3 / \mathrm{s}$ for both deterministic and statistic models, RMSE increases to the range of $1-4^{\circ} \mathrm{C}$ for larger rivers. These results indicate that water temperature modelling is generally less efficient on larger rivers (Benyahya et al. 2007, Westhoff et al. 2007).

The Hungarian Hydrological Forecasting Service predicts water temperature on the Hungarian reaches of the Danube and Tisza rivers on a daily basis. The research site selected for this paper is Paks station on the Hungarian Danube reach (Figure 1).

\footnotetext{
a Corresponding author: liptay.zoltan@ovf.hu DOI 10.3311/FLOODRisk2020.17.11
} 


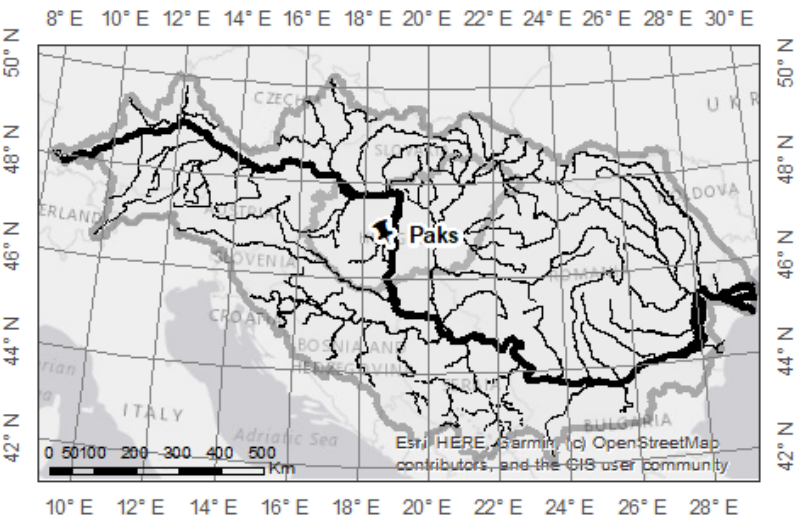

Figure 1. Map of the Danube catchment

\begin{tabular}{|c|c|c|c|c|}
\hline Author & Class & River & $\begin{array}{c}\text { RMSE } \\
\text { calib. } \\
{\left[{ }^{\circ} \mathrm{C}\right]}\end{array}$ & $\begin{array}{c}\text { RMSE } \\
\text { valid. } \\
{\left[{ }^{\circ} \mathrm{C}\right]}\end{array}$ \\
\hline $\begin{array}{c}\text { Ahmadi- } \\
\text { Nedushan et } \\
\text { al. (2007) }\end{array}$ & $\mathrm{S} / \mathrm{P}$ & Moisie & $0.50-0.51$ & $0.52-0.53$ \\
\hline $\begin{array}{l}\text { Westhoff et } \\
\text { al. (2007) }\end{array}$ & D & Maisbich & 1.01 & - \\
\hline $\begin{array}{l}\text { van Vliet et } \\
\text { al. (2012) }\end{array}$ & D & Danube & 2.5 & - \\
\hline $\begin{array}{c}\text { Toffolon \& } \\
\text { Piccolroaz } \\
\text { (2015) }\end{array}$ & D & $\begin{array}{c}\text { Mentue, } \\
\text { Dismabach } \\
\text { and Rhóne }\end{array}$ & $0.58-0.91$ & $0.62-1.05$ \\
\hline $\begin{array}{l}\text { Oullet-Prouéx } \\
\text { et al. (2017) }\end{array}$ & D & $\begin{array}{c}\text { Nechako } \\
\text { and } \\
\text { Miramichi }\end{array}$ & $1.37-1.38$ & $1.51-1.54$ \\
\hline $\begin{array}{c}\text { Zhang \& } \\
\text { Johnson } \\
(2017) \\
\end{array}$ & $\mathrm{S} / \mathrm{P}$ & Missouri & $1.74-3.53$ & - \\
\hline $\begin{array}{c}\text { Zhu et al. } \\
\text { (2018) }\end{array}$ & $\mathrm{S} / \mathrm{P}$ & Missouri & $1.72-3.94$ & - \\
\hline $\begin{array}{c}\text { Zhu et al. } \\
\text { (2018) }\end{array}$ & $\begin{array}{l}\mathrm{S} / \\
\mathrm{NP}\end{array}$ & Missouri & $1.49-1.97$ & - \\
\hline $\begin{array}{c}\text { Tavares et al. } \\
(2018)\end{array}$ & D & Cebollati & 1.29 & 1.24 \\
\hline $\begin{array}{c}\text { Piotrowski \& } \\
\text { Napiorkowski } \\
(2018) \\
\end{array}$ & D & $\begin{array}{c}\text { Biala } \\
\text { Tarnowska }\end{array}$ & 1.12 & 0.91 \\
\hline $\begin{array}{c}\text { Zhu et al. } \\
\text { (2019) }\end{array}$ & $\begin{array}{l}\mathrm{S} / \\
\mathrm{NP}\end{array}$ & Drava & $0.95-2.58$ & $1.30-2.73$ \\
\hline $\begin{array}{c}\text { Zhu et al. } \\
\text { (2019) }\end{array}$ & D & Drava & $0.87-1.04$ & $0.89-1.37$ \\
\hline
\end{tabular}

Table 1. Comparison of water temperature modelling results with other published studies.

The average annual discharge of the Danube River at Paks is $2324 \mathrm{~m}^{3} / \mathrm{s}$. The average water temperature in the study period was $12.82^{\circ} \mathrm{C}$, the minimum was $0.4^{\circ} \mathrm{C}$ and maximum was $26.8^{\circ} \mathrm{C}$. The study site is characterized by semihumid temperate climate with oceanic (mostly in summer months), continental (mostly in winter months) and Mediterranean influences (Gyarmati et al. 1997, Ács \& Bauer 2013). River ice typically occurs between December and early March. The average temperature of the coldest month (January) is around $0^{\circ} \mathrm{C}$. The number of frost days (daily minimum temperature $<0^{\circ} \mathrm{C}$ ) and the number of winter days (daily maximum temperature $<$ $0^{\circ} \mathrm{C}$ ) reflects the local ice generation potential of winter seasons. Several studies on the long-term evaluation of the number of frost days are available (Gyarmati et al. 1997, Szalai \& Szentimrey 2005, Kocsis 2018) that indicate slight decrement of -0.14 days/year. The number of frost and winter days show a wide variation across the country with an average of 90 to 100 frost days and 20 to 30 winter days along the Danube (Kocsis 2018). The gauging station at Paks is an important location for water temperature prediction due to the nuclear power plant located along the river and utilising cooling water.

This paper aims to present the operational water temperature and river ice prediction technics used by the Hungarian Hydrological Forecasting Service and compare their performance to artificial neural network solutions. The study aims to contribute to water temperature modelling of larger rivers.

\section{Materials and Methods}

\subsection{Deterministic method - The estimation of the energy balance}

The river ice and water temperature forecasting system for the Hungarian Danube reach has been developed and operated by the Hungarian Hydrological Forecasting Service. First of the methods is the estimation of the terms of the energy balance of water published by Starosolszky (1969) and many other e.g. Mohseni \& Stefan (1999). The model uses the observed water temperature as an initial condition and estimates the daily changes based on the energy balance driven mainly by the predicted air temperature of the ECMWF meteorological model. The governing equation of the energy balance is:

$$
\begin{aligned}
E_{0}-E_{u} & =(1-A) \cdot E_{s w} \\
& +E_{l w}-E_{s}+E_{c}+E_{e}+E_{p}
\end{aligned}
$$

Where $E_{o}$ is the total energy emitted or absorbed, $E_{u}$ is the energy flux through the river bed, $E_{s w}$ is the net solar (shortwave) radiation, $A$ is the albedo, $E_{l w}$ is the atmospheric (longwave) radiation, $E_{s}$ is the emitted longwave radiation of water surface, $E_{c}$ is the sensible heat transfer on the water-air boundary layer (convective heat flux), $E_{e}$ is the energy loss or gain from evaporation or vapor condensation (latent heat transfer or evaporative heat flux), $E_{p}$ is the energy from precipitation.

The clear sky (or blue sky) net shortwave radiation $\left(E_{s w 0}\right)$ is a sum of direct $\left(E_{s w d i r}\right)$ and diffuse $\left(E_{s w d i f}\right)$ radiations.

$$
E_{s w 0}=E_{s w d i r}+E_{s w d i f}
$$

Equations for direct solar radiation are available (Dozier 1979), its value can be estimated with sufficient accuracy based on the formulas of spherical trigonometry.

$$
\delta=\sin ^{-1}[0.398 \sin (\varepsilon)]
$$

Where $\delta$ is the declination angle. $\varepsilon$ the solar longitude. 


$$
\varepsilon=4.871+0.0175 d+0.033 \sin (0.0175 d)
$$

Where $d$ is the day of year. The hour angle $(\omega)$ is written as:

$$
\begin{aligned}
\omega=\lambda+0.043 & \sin (2 \varepsilon) \\
& -0.033 \sin (0.0175 d) \\
& +0.262 T_{u t c}-n
\end{aligned}
$$

Where $\lambda$ is the longitude in radian and $T_{u t c}$ is the hour in UTC. The solar elevation is calculated as:

$$
\alpha=\sin ^{-1}[\sin (\varphi) \sin (\delta)+\cos (\varphi) \cos (\delta) \cos (\omega)]
$$

Where $\varphi$ is the latitude in radian. The azimuth $(\beta)$ is written as:

$$
\beta=\sin ^{-1}[\cos (\delta) / \cos (\alpha) * \sin (\omega)]
$$

Finally the radiation angle $(\eta)$ is calculated by the following equation:

$$
\begin{array}{r}
\eta=\cos ^{-1}[\cos (\alpha) \sin (\gamma) \cos (\beta-\theta) \\
+\sin (\alpha) \cos (\gamma)]
\end{array}
$$

Where $\gamma$ is the slope angle in radian and $\theta$ is the exposure in radian. The exposure is $0^{\circ}$ at North, $90^{\circ}$ at East, $180^{\circ}$ South and $270^{\circ}$ at West. We multiply the direct shortwave radiation normal to the surface by the cosine of the radiation angle.

$$
S_{d i r}=S_{n} \cos (\eta)
$$

Where $S_{n}$ is the incoming shortwave radiation perpendicular to the surface.

$$
S_{n}=S_{c} \tau^{m}
$$

Where $S_{c}$ is the solar constant $\left(\sim 1380 \mathrm{~W} / \mathrm{m}^{2}\right), \tau$ is the atmospheric emissivity $(\sim 0.8)$ and $m$ is the exponent written as:

$$
m=\sqrt{1229+[614 \sin (\alpha)]^{2}}-614 \sin (\alpha)
$$

The estimation of the diffuse component of shortwave radiation is not as exact. We use the following empirical equation (Liu and Jordan 1960, Gates 1980, Linacre 1992, Oliphant et al. 2006):

$$
E_{\text {swdif }}=S_{c}\left(0,271-0,294 \tau^{m 0}\right) S_{e}
$$

Where $E_{\text {rhdif }}$ is the diffuse shortwave radiation $\left[\mathrm{J} / \mathrm{m}^{2} \mathrm{~s}\right]$, $S_{c}$ is the solar constant $\left[\mathrm{J} / \mathrm{m}^{2} \mathrm{~s}\right], S_{e}$ is the solar elevation [rad], $\tau$ is the atmospheric transmission coefficient and $m_{0}$ is derived from the following equation:

$$
m 0=\sqrt{1229+\left(614 \sin S_{e}\right)^{2}-614 \sin S_{e}}
$$

In case of cloud cover the net shortwave radiation is a portion of the clear sky value:

$$
E_{s w}=E_{s w 0}\left(1,0-F_{s} C N_{f}{ }^{F_{k}}\right)
$$

Where $F_{s}$ and $F_{k}$ are constants, and $N_{f}$ is the cloud covertness. If the cloud covertness is unknown, for example while making predictions, we estimate it based on the daily minimal $\left(T_{\min }\right)$ and maximal $\left(T_{\max }\right)$ air temperatures.

$$
N_{f}=a_{c}+b_{c}\left(T_{\max }-T_{\min }\right)
$$

Where $a_{c}$ and $b_{c}$ are empirical parameters.

The albedo of water has a significant effect on shortwave radiation. The small angles of low solar elevation cause $90 \%$ of the radiation to be reflected, while high summer elevations result only in $2-3 \%$ reflection. The albedo of water is a complex problem, thus only a simple approximation of the Fresnel equations is included based on solar elevation as the angle of incidence. As a result albedo ranges from 1.0 at $0^{\circ}$ and 0.025 above $50^{\circ}$.

The longwave atmospheric radiation is based on the Stefan-Boltzmann Law (Stephan 1879, Boltzmann 1884):

$$
E_{l w}=\varepsilon_{a} \sigma T_{a}^{4}
$$

Where $E_{l w}$ is the longwave radiation $\left[\mathrm{J} / \mathrm{m}^{2} \mathrm{~s}\right], \varepsilon_{a}$ is the nocturnal radiation coefficient, $\sigma$ is the Stefan-Boltzmann constant $\left[5.73510^{-8} \mathrm{~J} / \mathrm{m}^{2} \mathrm{~K}^{4} \mathrm{~s}\right], T_{a}$ is the atmospheric temperature $\left[{ }^{\circ} \mathrm{K}\right]$. The nocturnal radiation coefficient is calculated by Brunt's expression written as:

$$
\varepsilon_{a}=(a+b \sqrt{e})
$$

Where $a$ and $b$ are constants, $e$ is the vapor pressure [mbar]. Cloud covertness is also a factor, thus we take it into account by the following expression:

$$
\varepsilon_{a}=\varepsilon_{a}\left(1+D_{c} \cdot N_{f}\right)
$$

Where $D_{c}$ is a constant. We consider $\varepsilon_{a}$ to be unity in case of full cloud cover. The main sources of atmospheric radiation are clouds, thus we approximate the atmospheric temperature with cloud temperature. We consider cloud temperature to differ from air temperature by a constant value. The atmospheric temperature is written as:

$$
T_{a}=T_{\text {air }}+0,1\left(N_{f} \Delta T\right)
$$

Where $T_{\text {air }}$ is the air temperature, $\Delta T$ is the difference of air and cloud temperatures.

The emitted longwave radiation of water surface is also calculated based on the Stefan-Boltzmann Law, using the radiation coefficient of water $\left(\varepsilon_{w}\right)$.

The convective heat flux $\left(E_{c}\right)$ is written as:

$$
E_{c}=\left(D_{c} \cdot u\right)\left(T_{a i r}-T_{w}\right)
$$

Where $D_{c}$ is a constant, $u$ is the wind speed $[\mathrm{m} / \mathrm{s}]$, and $T_{w}$ is the water temperature. Evaporative heat flux is calculated by the following expression: 


$$
E_{e}=\left(D_{e} \cdot u\right)\left(e_{a i r}-e_{w}\right)
$$

Where $D_{e}$ is a constant, $u$ is the wind speed [m/s], eair is the vapor pressure of air [mbar], $e_{w}$ is the vapor pressure of water [mbar], and $T_{w}$ is the water temperature.

The energy from liquid precipitation $\left(E_{p}\right)$ is written as:

$$
E_{p}=4210 T_{p} P
$$

Where $T_{p}$ is the temperature of the precipitation and $P$ is the intensity of the precipitation. The temperature of precipitation is practically considered to be equal to air temperature. We consider this value to be neglected in case of rivers. On the other hand the major influence of underground sources has to be introduced. These sources have a cooling effect during summer seasons and heating effect during winter seasons. The temperature of these sources are considered to be equal to the average water temperature, and the heat flux is written as:

$$
E_{u}=D_{u}\left(\overline{T_{w}}-T_{w}\right)
$$

Where $E_{u}$ is the heat flux of underground sources $\left[\mathrm{J} / \mathrm{m}^{2} \mathrm{~s}\right], \overline{T_{w}}$ is the average water temperature, and $D_{u}$ is a constant.

When the predicted water temperature reaches the freezing point and further cooling is expected, the energy loss is then turn onto the change of state from water to ice. The calculation algorithm reports the beginning of ice run and switches to the summation of negative temperatures. Three threshold values characterises the further behaviour, the threshold for ice cover, the threshold for the end if ice cover and the threshold for the end of ice run. This approach is also empirical and relies on continuous analysis of icy events and recalibration of threshold values but provides satisfactory results on the major Hungarian rivers (Hirling 1981, Keve 2018).

\subsection{Conceptual method - The weighted mean temperatures}

The theory, published by the Swedish meteorologist Olof Bertil Rodhe in 1952 and later in 1955, was an answer to the uncertain approach of temperature sum based methods (Östman 1950, Nusser 1950, Palosuo 1951) of that era. This approach was specifically developed for marine application, to predict the appearance and later the extension of shore ice along the Baltic coastline. The U.S. Army Cold Regions Research and Engineering Laboratory experimented with river application and presented promising results (Bilello 1963), and also recommended Rodhe's method for further testing on river ice prediction. Liptay (2018/a) also applied the method for the Hungarian Danube reach with promising results.

Although the theory of energy balance had been known for a long time, meteorological measurements were unable to provide the necessary input data for the calculation of the energy balance till the end of the 1960s (Csoma 1968). Rhode assumed that all terms of the full energy balance are neglected but the direct energy transfer between water and air.

$$
\frac{d \tau}{d t}=k(T-\tau)
$$

Where $T$ is the air temperature $\left[{ }^{\circ} \mathrm{C}\right], \tau$ is the water temperature $\left[{ }^{\circ} \mathrm{C}\right], t$ is the time $[\mathrm{s}]$ and $k$ is a the time inverse coefficient $[1 / \mathrm{s}]$ or a constant with inverse dimension of time. After the solution and discretization of the basic differential equation (24), the final form is equation 25 .

$$
\tau_{n}=\tau_{n-1}+\left(1-e^{-k \Delta t}\right)\left(T_{n}-\tau_{n-1}\right)
$$

Where $T_{n}$ is the average air temperature at a time step $\mathrm{t}_{\mathrm{n}-1}-\mathrm{t}_{\mathrm{n}}\left[{ }^{\circ} \mathrm{C}\right], \tau_{n}$ is the temperature of the water surface at $t_{n}$ $\left[{ }^{\circ} \mathrm{C}\right], \tau_{n-1}$ is the temperature of the water surface at $t_{n-1}\left[{ }^{\circ} \mathrm{C}\right]$, $\Delta t$ is time step [s].

In the theory of weighted mean temperatures $k$ is considered to be a constant, and its value is selected to drive Eq. 16. to zero when ice is expected. It is also possible to find a value for $k$ where the series of calculated and observed water temperatures have the highest correlation (Liptay 2018/b). Mohseni \& Stefan (1999) presented that the air temperature and water temperature has an S-shaped relation. This relation is presented for Paks on Figure 2. A polynomial trend line is also shown with the coefficient of determination of 0.88 .

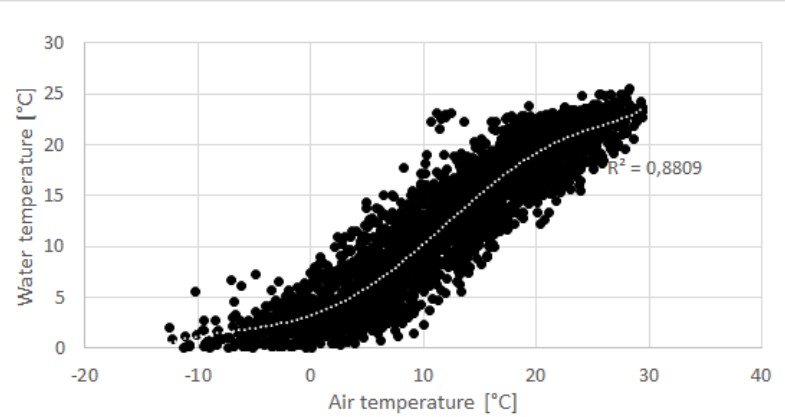

Figure 2. The relation of air temperature and water temperature at Paks

We consider this relation as a sigmoid function $(\sigma(x))$ such as the standard logistic function, the normal cumulative distribution function, or the tangent hyperbolic function just to name a few. The first derivative of $\sigma(x)$ gives the measure of the rate at which water temperature changes with respect to the change of air temperature as a continuous function. The standard logistic is written as:

$$
\sigma(x)=\frac{1}{1+e^{-x}}=\frac{e^{x}}{1+e^{x}}
$$

Where $e$ is the natural logarithm base. The derivative of this function is easily calculated:

$$
\sigma^{\prime}(x)=\sigma(x)[1-\sigma(x)]=\frac{e^{x}}{\left(1+e^{x}\right)^{2}}
$$

The graphical representation is on Figure 3. 


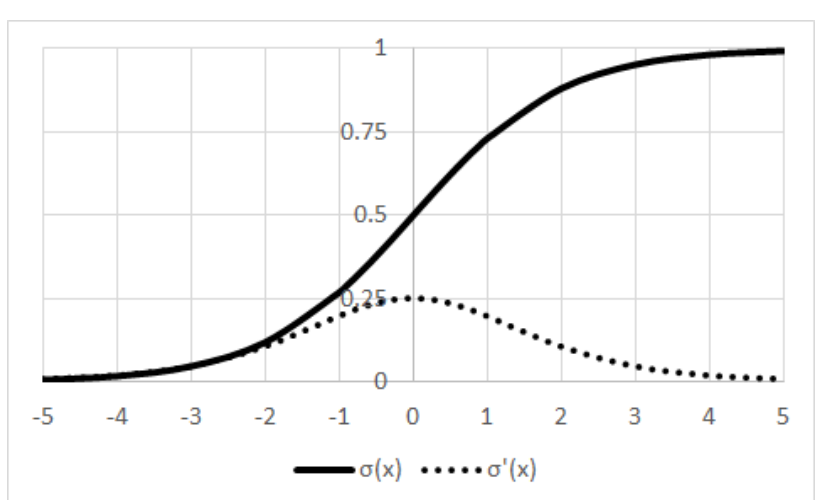

Figure 3. The standard logistic function $(\sigma(x))$ and its first derivate $\left(\sigma^{\prime}(x)\right)$. function:

Considering a more general form of the logistic

$$
\sigma(x)=\frac{a}{1+e^{\left(-\frac{x}{b}+c\right)}}
$$

Where the additional parameter $a$ is the scale, $b$ is the steepness and $c$ is the shift for the transformation of the standard function. The derivate of this function is written as:

$$
\sigma^{\prime}(x)=\frac{a e^{\left(-\frac{x}{b}+c\right)}}{b\left[1+e^{\left(-\frac{x}{b}+c\right)}\right]^{2}}
$$

With these additional parameters the derivative function can be transformed into the range of $k$ values of Eq. 24 and 25., but for the proper description of the dependency it also has to be reversed. To reverse the derivative function we simply deduct it from unity. Finally the formula for $\mathrm{k}$ is written as:

$$
k=k_{m}\left(1-\sigma^{\prime}(x)\right)
$$

Where $k_{m}$ is the maximum value for $k$ at the lowest and highest water temperatures.

A significant increment in model performance was achieved by substituting the local air temperature with a simple formula representing the convection of wate temperature from an upstream station. In Eq. 25. we define $T_{n}$ as:

$$
T_{n}=z * T_{n, l}+(1-z) T_{n-m, u}
$$

Where $T_{n, l}$ is the local daily mean air temperature $\left[{ }^{\circ} \mathrm{C}\right]$, $T_{n-m, u}$ is the daily mean air temperature of an upstream station $\left[{ }^{\circ} \mathrm{C}\right]$ at a distance of $m$ time steps, $z$ is a factor dependent on flow regime [-].

$$
z=1-\left(M T_{n} * s\right)
$$

Where $M T_{n}$ is the daily value of flow regime [\%], $s$ is a constant. The value of $s$ should be chosen to simulate the local impact during low flow and increasing weight of upstream impact with raising water level. It is usually in the range of small positive numbers, 1 to 5 .

As ice appears on the surface of rivers the process of energy exchange is influenced. In order to describe this effect we introduced an additional factor $(r)$ for $k$ when the calculated water temperatures are under $0^{\circ} \mathrm{C}$.

$k=\left\{\begin{array}{lr}k & \text { if } \tau_{n-1}>0 \\ k \cdot r & \text { if } \tau_{n-1}<0 \text { and }\left(T_{n}-\tau_{n-1}\right)<0 \\ \frac{k}{r} & \text { if } \tau_{n-1}<0 \text { and }\left(T_{n}-\tau_{n-1}\right)>0\end{array}\right\}$ (31)

\subsection{Non-parametric statistic method - Artificial Neural Network}

The machine learning type artificial intelligence approaches have a long history reaching back to the work of McCulloch \& Pitts (1943). Rosenblatt (1957) presented the concept of a perceptron but it got great interest only after its rediscovery by Rumelhart et al. (1986). The nonlinearity of the multilayer perceptron (MLP) was a significant advantage compared to the linear behaviour of the Rosenblatt perceptron, and by the error propagation method it was possible to find the weights of the internal synapses. The first hydrological application of artificial neural network (ANN) was by Daniel (1991) but it was followed by a great number of studies and it is still an intensively studied area. Comprehensive reviews on neural hydrology (or neurohydrology) were made by Govindaraju (2000/a and 2000/b) and Tanty \& Desmukh (2015), while numerous case studies are also available (Rabi et al. 2015, Temizyurek \& Dadaşer-Çelik 2018, Zhu et al. 2018, Zhu et al. 2019).

An ANN is considered as a black box model and by opening this box one does not find the representation of the physical processes, thus method extraction is not yet possible. It is an artificial architecture consisting of neurons and synapses resembling the biological cognition and its information processing characteristics.

A schematic representation of a neuron is presented on Figure 4.

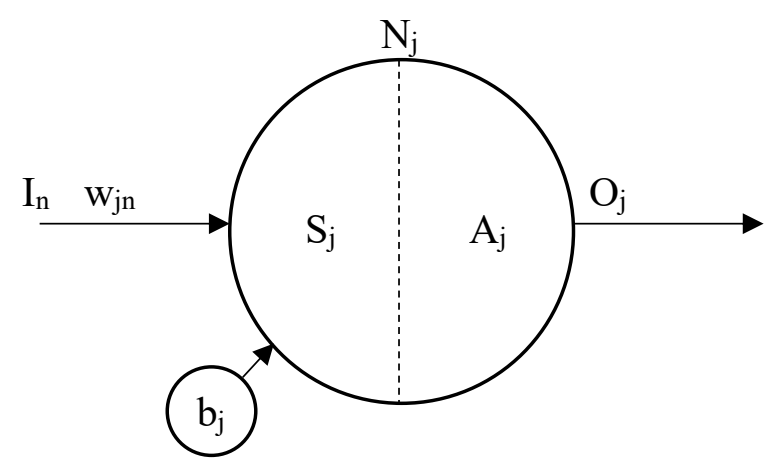

Figure 4. Schematic diagram of a neuron.

From left to right the $j$-th neuron $\left(N_{j}\right)$ has $n$ number of inputs $\left(I_{n}\right)$ with $w_{j n}$ weights of the synapses and it has a $b$ bias value. These are summed as: 


$$
S_{j}=\sum_{i=1}^{n} I_{i} w_{j i}+b
$$

All neurons have a transfer or activation function $\left(A_{\dot{f}}\right)$ which is usually of sigmoid type. If we take the aforementioned logistic function, the $O_{j}$ output of the neuron will be written as:

$$
O_{j}=A_{j}=\frac{1}{1+e^{-S_{j}}}
$$

The feed forward MLP stands of at least three layers of neurons: input, hidden and output layers. The neurons of the input layer have only one input per neuron and both the input and output layers have linear transfer function, thus:

$$
O_{j}=S_{j}
$$

The schematic diagram of a feed forward multilayer perceptron is shown on Figure 5.

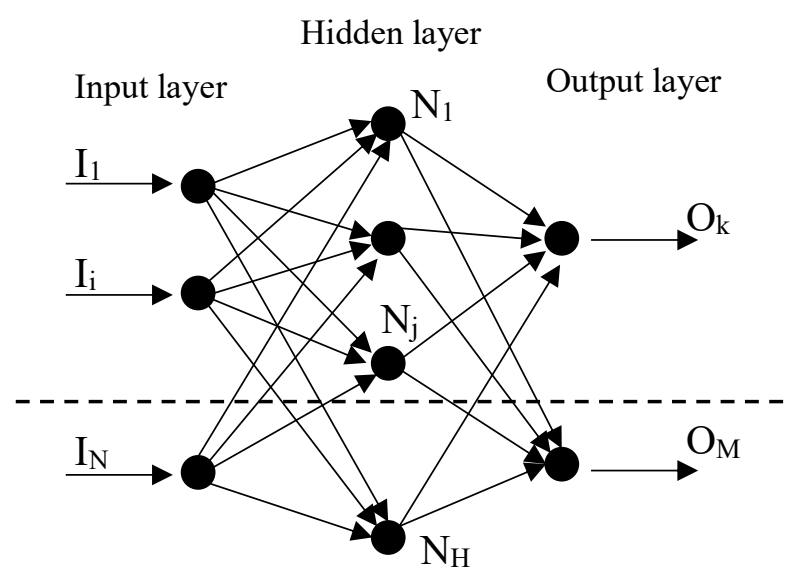

Figure 5. Schematic diagram of a feed forward multilayer perceptron.

Classifications and regressions are two possible applications of ANNs. Speaking of either appliation some inputs are given at the input layer and outputs are received at the output layer. These outputs are compared to target $(T)$ values and based on the errors $(E)$ the ANN is able to learn (Rumelhart et al. 1986).

$$
E=\frac{1}{2} \sum_{k=1}^{M}\left(T_{k}-O_{k}\right)^{2}
$$

This training method requires a great number of training data carefully selected to describe the general range of the resembled process because the extrapolation capabilities of an ANN are poor (Govindaraju 2000/b). We used the widely applied error back-propagation with added momentum for the training process. For any weight (Eq. 35.) and bias (Eq. 36.) in the network the formula is written as:

$$
\begin{gathered}
w_{k j}(t+1)=w_{k j}(t)-\alpha \frac{\partial E}{\partial w_{k j}}+\beta \Delta w_{k j}(t-1) \\
b_{j}(t+1)=b_{j}(t)-\alpha \frac{\partial E}{\partial b_{j}}+\beta \Delta b_{j}(t-1)
\end{gathered}
$$

Where $\alpha$ is the learning rate, $\beta$ is the momentum, $t$ is a training step. We used the tangent hyperbolic function as an activation function, thus the partial derivative of the error after the application of the chain rule in the output layer is:

$$
\frac{\partial E}{\partial w_{k j}}=\frac{\partial E}{\partial O_{k}} \frac{\partial O_{k}}{\partial S_{k}} \frac{\partial S_{k}}{\partial w_{k j}}=-\left(T_{k}-O_{k}\right) O_{j}
$$

In the hidden layer it is:

$$
\frac{\partial E}{\partial w_{j i}}=\sum_{k=1}^{M}\left(\frac{\partial E}{\partial w_{k j}} w_{k j}\right) \tanh ^{\prime}\left(S_{j}\right) O_{i}
$$

The formulas for the biases $(b)$ are similar except they do not have any inputs so the multiplication with the output $(O)$ of the previous layer is missing.

We built two different architectures. The first approach was a single output MLP specified for a single water temperature prediction of a defined lead time from 1 to 10 days. The number of the input neurons was one for the latest observed water temperature and additional input neurons for each days of air temperature forecast during the lead time. So the MLP for 1 day lead time had 2 input neurons, while the MLP for 10 days had 11 inputs. This approach required the construction and the training of 10 ANNs. The second approach was to predict the entire time series of 10 days of water temperature with a single MLP. The number of input neurons was 11 and the number of output neurons was 10 in this case.

Zhu et al. (2019) assessed the performance of neural nets for daily water temperature prediction and found increasing performance with added flow discharge and day of the year (DOY) as predictors, however discharge did not have significant effect on lowland rivers. We also made tests with added DOY, but it did not have positive effect on the results.

Woking with ANNs requires heuristic approaches. There are formulas for the minimal number of weights and optimal network architectures such as the LevenbergMarquardt algorithm and Bayesian regularisation (Rabi et al. 2015, Sariev \& Germano 2019), but it still requires a great number of experimentations to achieve the best results. These algorithms were not used for the current study, we rather combined the networks with early stopping by simultaneously monitoring the validation errors as test errors.

For the first approach we used 6 hidden layers with decreasing number of neurons, from 6 in the first hidden layer and 2 in the last. For the second approach there were 3 hidden layers with 13, 12 and 11 neurons. These structures gave the best results after a long experimentations process. 


\subsection{Calibration and validation}

The time period selected for the comparison was from $01 / 07 / 2015$ to $30 / 06 / 2019$ (Figure 6). This period is divided into three sub periods:

1. Calibration (c): 01/07/2015-30/06/2017

2. Validation 1. (v1): 01/07/2017-30/06/2018

3. Validation 2. (v2): 01/07/2018-30/06/2019

The calibration period contained a heavy ice run from $07 / 01 / 2017$ to $04 / 02 / 2017$, while the validation periods were ice free. There were a few days of erroneous observation at the beginning of the $v 2$ validation period due to sludge cover on the sensor.

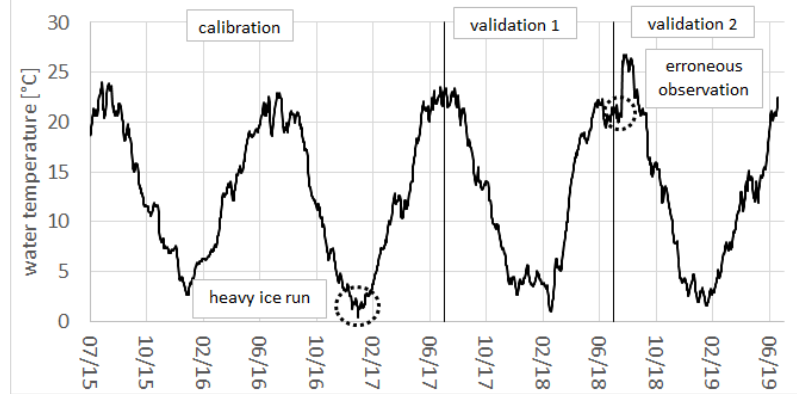

Figure 6. The time series of observed water temperatures on the Danube River at Paks.

Each of the models was trained on the first sub period and validated on the second and third periods. The calibration technic was different for each of the models, but the target function was the minimisation of the root mean square error in each case. The RMSE was also the basis of the comparison.

The deterministic method has 10 calibration variables, thus an automatic calibration procedure was applied to achieve the best result. The deterministic model was used only for the lead time of 6 days. The conceptual method has 6 calibration variables and a trial-and-error based manual calibration was carried out on them. The training of the neural networks was based on the error backpropagation method as described earlier through several thousands of epochs. Overfitting easily happens with high learning rate, but shallow learning curve is experienced with low learning rate. To slightly overcome this behaviour we introduced a trigonometrically changing learning rate depending on the number of the actual epoch.

\section{Results}

\subsection{Water temperature simulation}

The resulting RMSE values obtained at the calibration and validation processes for the deterministic estimation of the energy balance (EEB) and the conceptual sigmoid sum of weighted mean temperatures are shown on Figure 7.

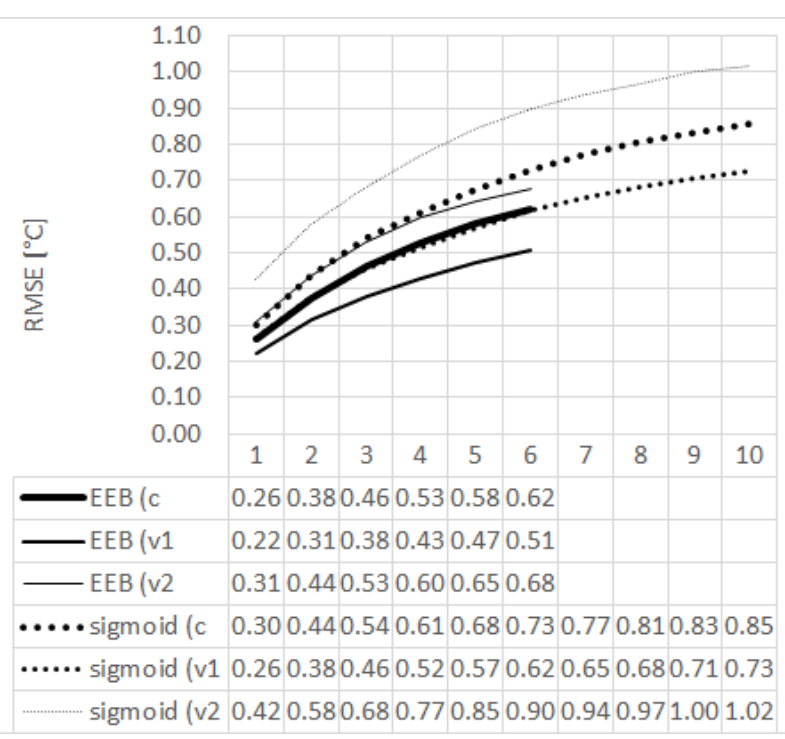

Figure 7. The calibration and validation results of the deterministic and conceptual methods.

Both models showed similar behaviour meaning the $v 1$ validation gave the closest fit to the observation followed by the calibration. However the $v 2$ validation showed slightly worse performance for the deterministic model, it was a significantly decrement in performance for the conceptual model.

The resulting RMSE values for the two MLPs are presented on Figure 8.

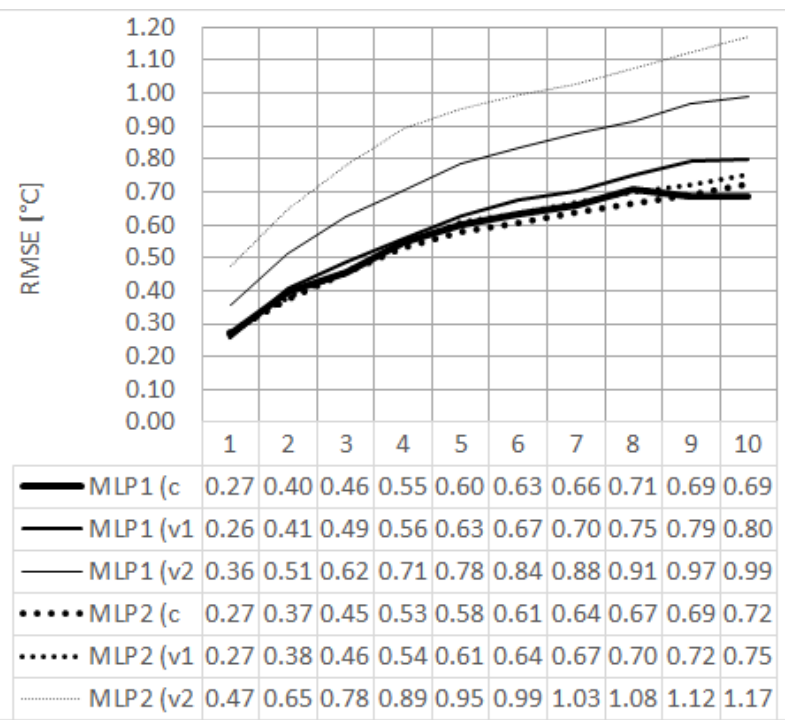

Figure 8. The training and validation results of the single and time series output MLPs.

The results of the MLPs show a different behaviour. A close fit was achieved during the training process that did not change significantly during the $v 1$ validation, but the $v 2$ validation showed poor performance for both MPLs.

On Figure 9 we presented the RMSE values of the conceptual method and the MPLs as a proportion of the RMSE of the deterministic method for the 6 days of lead time. 


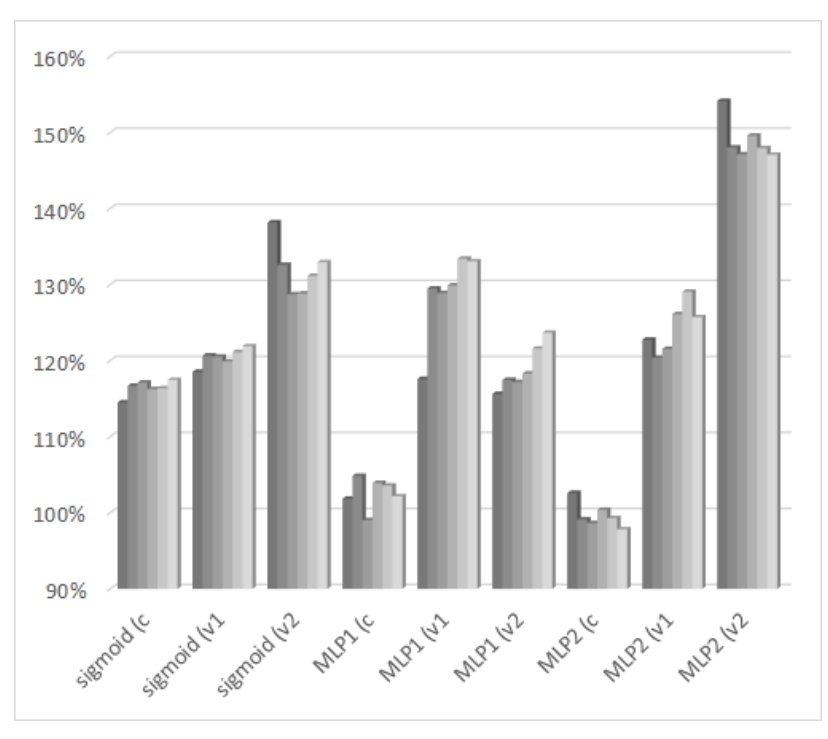

Figure 9. Comparison of the calibration and validation RMSE of the conceptual model and the MLPs as a proportion of the RMSE of the deterministic method for 6 days of lead time.

While the conceptual method seemed to present slightly inferior performance through all the simulations, the MLPs showed similar or slightly superior performance for the calibration and significantly inferior performance during the validation. Surprisingly MLP1 gave the best results out of the three non-deterministic approaches for the $v 2$ validation period, but it is still a poor performance compared to the deterministic method.

\subsection{River ice prediction}

The models were calibrated to achieve the minimal RMSE for water temperature simulation during the calibration period, but there was a month of heavy ice run from $07 / 01 / 2017$ to $04 / 02 / 2017$ in this timespan. The observed water temperatures during ice run were still positive due to the placement of the sensor on the river bed. It results in a misleading initial condition for the models for ice prediction so we evaluated the simulated values when the appearance of river ice is only in the forecasted period.

The deterministic method consistently simulated negative water temperature on $08 / 01 / 2017$, one day later than the actual ice run started. The conceptual method predicted negative water temperature consistently for $11 / 01 / 2017$, four days after the observed ice run. The simulation was also carried out without the latest observed water temperature as the initial condition and purely based on mean air temperatures. It predicted ice on 10/01/2017, only one day earlier. Superior results are presented by Liptay (2018/a and 2018/b) with this method if the lag value is chosen for ice prediction.

The MLPs did not provided negative water temperatures as they were trained to fit the observed time series as much as possible, not to describe the physical behaviour.

\subsection{Erroneous observation data}

Since the latest observation data was used as initial condition for all the models its errors clearly spread onto the simulated values. Erroneous observations were present in the water temperature time series used for the $v 2$ validation period (Figure 6). Due to extremely low water levels and unexpected hydraulic conditions the water level and temperature sensor was covered with river sludge which resulted in abnormally low observed temperatures. After the sensor was cleaned extremely high values were observed that were expected based on neighbouring stations and the circumstances.

Validation of the observed data is highly recommended for any of the models applied in this paper. Such a validation process could be the long term simulation of water temperatures with the conceptual method. Long term simulation means that only the mean air temperatures and the water levels are supplied to the model after the initial water temperature. In such a case the initial water temperature could also be approximated by a monthly mean value. Due to its low computation capacity requirements, low data need and lower number of parameters the conceptual model is easy to setup and carry out, while the results could serve as basis for validation. The conceptual method had an RMSE of $1.1^{\circ} \mathrm{C}$ during a long term simulation of the calibration period, $0.73{ }^{\circ} \mathrm{C}$ for $v 1$ and $1.03^{\circ} \mathrm{C}$ for $v 2$. Using these as threshold values a qualification of the observation is possible.

\section{Discussion}

We compared three different water temperature simulation approaches in this paper. The physically based deterministic energy balance method, the conceptual theory of weighted mean temperatures, and a nonparametric statistical method, the artificial neural networks. Calibration and validation results showed that the physically based method is superior in water temperature and river ice prediction compared to other approaches, however it requires a great number of equations and parameters. The conceptual method showed a simple, thus slightly inferior representation of the physical processes. The constructed artificial neural networks were applied as regression architectures and while they showed great performance during the calibration, validation results remained inferior. It is confirmed by the widely cited behaviour of neural networks. They are good general interpolators, but inferior extrapolators (Govindaraju 2000/a). Validation in this case was more or less extrapolation as the combination of input data was of high variety.

\section{References}

1. Ács, F., Bauer, H. (2013): Biofizikai éghajlatosztályozási módszerek. Eötvös Lóránd Tudományegyetem.

2. Ahmadi-Nedushan, B., St-Hilaire, A., Ouarda, T., B., M., J., Bilodeau, L., Robichaud, É., Thiémonge, N., Bobeé, B. (2007): Predicting river water temperatures 
using stochastic models: case study of the Moisie River. Hydrological Processes. 21, 21-34. doi:10.1002/hyp.6353

3. Benyahya, L., Caissie, D., St-Hilaire, A., Ouarda, T., B., M., J., Bobée, B. (2007): A review of statistical water temperature models. Canadian Water Resources Journal. 32/3, 179-192.

4. Bilello, M., E. (1963): Method of predicting river and lake ice formation. U.S. Army Cold Regions Research and Engineering Laboratory, Hanover.

5. Boltzmann, L (1884): Ableitung des Stefan'schen Gesetzes, betreffend die Abhängigkeit der Wärmestrahlungvon der Temperatur aus der electromagnetischen Lichttheorie. Ann. der Phys. und Chemie.22, 291(1884)

6. Brunt, D. (1939): Physical and dynamical meteorology. Cambridge, Cambridge Univ. Press, p. 136.

7. Csoma, J. (1968): A Tisza jégjelenségeinek előrejelzése. Vízügyi Közlemények. 50/3, 326-365.

8. Daniel, T., M. (1991): Neural networks - application in hydrology and water resources engineering. Proc. Int. Hydrol. and Water Resour., Institution of Engineers, Perth, Australia.

9. Dozier, J. (1979): A solar radiaton model for a snow surface in mountainous terrain. In "Modeling Snow Cover Runoff” (S. C. Colbeck and M. Ray, eds.), pp. 144-153. U.S. Army Cold Reg. Re. Eng. Lab., Hanover, New Hampshire

10. Gates, D. M. (1980): Biophysical ecology.New York: Springer-Verlag. 611 pp.

11. Govindaraju, R. (2000/a): Artificial Neural Networks in hydrology. I: Preliminary concepts. J. Hydrol. Eng.. 5/2. 115-123.

DOI:10.1061/(ASCE)1084-0699(2000)5:2(115)

12. Govindaraju, R. (2000/b): Artificial Neural Networks in hydrology. II: Hydrologic applications. J. Hydrol. Eng.. 5/2. 124-137. DOI: 10.1061/(ASCE)1084-0699(2000)5:2(124)

13. Gyarmati, Gy., Püski, L., Barta, R. (1997): Magyarország a XX. században. (edited by Kollega, T., I.) Babits Kiadó, Szekszárd.

14. Hirling, Gy. (1981): A Duna és a Tisza jégjelenségeinek előrejelzése. VIZDOK. Budapest

15. Keve, G. (2012): 2012. évi dunai jégészlelés tapasztalatai. ADU-NEKI beszámoló jelentés a 2012. évi dunai jégészlelésről. Baja.

16. Keve, G. (2018): Folyami jégészlelés fejlesztési lehetőségei. Budapesti Müszaki Egyetem. Budapest.

17. Kocsis, K. (2018): Magyarország nemzeti atlasza: természeti környezet. Magyar Tudományos Akadémia, Csillagászati és Földtudományi Kutatóközpont, Földrajztudományi Intézet, Budapest.

18. Linacre, E. T. (1992): Data-sparse estimation of lake evaporation, using a simplified penman equation. Agricultural and Forest Meteorology 64,237-256.

19. Liptay, Z., Á. (2018/a): Jégmegjelenés előrejelzése a súlyozott középhőmérsékletek elve alapján a Duna hazai szakaszára. Hidrológiai Közlöny 98, 1, 25-32

20. Liptay, Z., Á. (2018/b): Numerikus hidrológiai modellezés és folyami jégviszonyok előrejelzése. Pécsi Tudományegyetem, Pécs.
21. Liu, B., Y., H. and Jordan, R., C. (1960): The interrelationship and characteristic distribution of direct, diffuse and total solar radiation. Solar Energy 1960;4(3): 1

22. McCalloch, W., S. and Pitts, W. (1943): A logic calculus of the ideas immanent in nervous activity. Bull. of Math. Biophys., 5, 115-133.

23. Mladenović, B., M., Gombás, K., Liška, I. and Balatonyi, L. (2018): Report on the ice event 2017 in the Danube river basin. ICPDR, Vienna.

24. Mohseni, O. and Stefan, H., G. (1999): Stream temperature/air temperature relationship: a physical interpretation. Journal of Hydrology. 218, 128-141.

25. Nusser, F. (1950): Gebiete gleicher Eisvorbereitungszeit an den deuschen Küsten. Deutsche Hydrographische Zeitschrift. 3, 3/4.

26. Oliphant, A., Susan, C., Grimmon, B., Schmid, H., P. and Wayson, C., A. (2006): Local-scale heterogeneity of photosynthetically active radiation (PAR), absorbed PAR and net radiation as a function of topography, sky conditions and leaf area index. Remote Sensing of Environment. 103/324-337 https://doi.org/10.1016/j.rse.2005.09.021

27. Ouellet-Proulx, S., St-Hilaire, A., Boucher, M-A. (2017): Water temperature Ensemble Forecasts: Implementation using the CEQUEAU model on two contrasted river systems. Water. 9/457. doi: $10.3390 /$ w9070457

28. Östman, C., J. (1950): Om sambandet mellan köldsummor, isläggning och istjocklek. Meddelanden írån Sveriges meteorologiska och hydrologiska institut. Serie A. N:o 1.

29. Palosuo, E. (1951): Ice in the Baltic and the Meteorological Factors. Journal du Conceil International pour l'Exploration de la Mer. 17,2

30. Piotrowski, A., P., Napiorkowski, J., J. (2018): Performance of the air2stream model that relates air and stream water temperatures depends on the calibration method. Journal of Hydrology. 561/395412.

31. Rabi, A., Hadzima-Nyarko, M. and Sperac, M. (2015): Modelling river temperarure from air temperature: case of the River Drava (Croatia). Hydrological Sciences Journal. 60/9:1490-1507. https://doi.org/10.1080/02626667.2014.914215

32. Rodhe, B. (1952): On the relation between air temperautre and ice formation in the Baltic. Geografiska Annaler. 34, 175-202, Stockholm

33. Rodhe, B. (1955): A study of the correlation between the ice extent, the course of air temperature and the sea surface tenperature in the Alland Archipelago. Geografiska Annaler, 37, 141-163, Stockholm

34. Rosanblatt, F. (1957): The perceptron. A perceiving and recognizing automaton. Cornell Aeronautical Laboratory, Buffalo, New York.

35. Rumelhart, D., E., Hinton, G., E. and Williams, R., J. (1986): Learning internal representations by error propagation. Parallel distributed processing, MIT Press, Cambridge. 1, 318-362.

36. Sariev, E. and Germano, G. (2019): Bayesian regularized artificial neural networks for the 
estimation of the probability of default. Quantitave Finance. 20/2:311-328

https://doi.org/10.1080/14697688.2019.1633014

37. Starosolszky, Ö. (1969): A jég a vízépítésben. Vízgazdálkodási Tudományos Kutató Intézet. Budapest.

38. Stefan, J. (1879): Über die beziehung zwischen der wärmestrahlung und der temperatur. Wiener Ber. II 79,391 (1879)

39. Szalai, S., Szentimrey, T. (2005): Melegedett-e Magyarország éghajlata a XX. században? Statisztikai Szemle, 83/10-11, 978-989

https://doi.org/10.1016/j.jhydrol.2018.04.016

40. Tanty, R. and Desmukh, T. (2015): Application of Artificial Neural Network in Hydrology- A Review. International Journal of Engineering Research and. $4 / 6$.

DOI: $10.17577 /$ IJERTV4IS060247.

41. Taveres, M., H., da Cunha, A., H., F., Ruhoff, A., de Motta Marques, D. (2018): Applying a water temperature model to river and calibrating it with downscaled remote sensing data. Geophysical Research Abstracts. 20, EGU2018-15016.

42. Temizyurek, M. and Dadaşer-Çelik, F. (2018): Modelling the effects of meteorological parameters on water temperature using artificial neural networks. Water Sci Technol. 77(5-6):1724-1733. doi: 10.2166/wst.2018.058.

43. Toffolon, M., Piccolroaz, S. (2015): A hybrid model for river water temperature as a function of air temperature and discharge. Environmental Research
Letters. $\quad 10 . \quad 114011$ doi:10.1088/17489326/10/11/114011.

44. van Vliet, M., T., H., Yearsely, J., R., Franssen,W., H., P., Ludwig, F., Haddeland, I., Lettenmaier, D., P., Kabat, P. (2012): Coupled daily streamflow and water temperature modelling in large river basins. Hydrol. Earth Syst. Syi. 16, 4303-4321. doi:10.5194/hess-164303-2012

45. Westhoff, M., Hubert, S., Luxemburg, W., Stelling, G., van de Giesen, N., Selker, J., Pfister, L., Uhlenbrook, S. (2007): A distributed stream temperature model using high resolution temperature observations. Hydrology and Earth System Sciences, 11. 4., https://doi.org/10.5194/hess-11-1469-2007

46. Zhang, Z., Johnson, B., E. (2017): Hydrologic Engineering Center - River Analysis System (HECRAS) water temperature models developed for the Missouri River Recovery Management Plan and Environmental Impact Statement. US Army Corps of Engineers.

47. Zhu, S., Nyarko, E., K., Hadzima-Nyarko, M. (2018): Modelling daily water temperature from air temperature for the Missouri River. PeerJ 6:e4894; http://doi.org/10.7717/peerj.4894

48. Zhu, S., Nyarko, E., K., Hadzima-Nyarko, M., Heddam, S., Wu, S. (2019): Assessing the performance of a suite of machine learning models for daily river water temperature prediction. PeerJ. 7:e7065 http://doi.org/10.7717/peerj.7065 